\title{
FOREST DYNAMICS OF A SUB-XEROPHILOUS VEGETATION FORMATION IN CENTRAL PERU - CHANCHAMAYO VALLEY, PERU ${ }^{1}$
}

\author{
Sonia Palacios-Ramos ${ }^{2 *}$, Rolando Montenegro ${ }^{2}$, Reynaldo Linares-Palomino ${ }^{3}$ and Carlos Reynel ${ }^{2}$
}

\footnotetext{
${ }^{1}$ Received on 31.01.2018 accepted for publication on 11.10.2018.

${ }^{2}$ Universidade Nacional Agrária La Molina, Faculdade de Ciências Florestais, Lima - Perú. E-mail: <soniapalacios@lamolina.edu.pe>, $<$ rmontenegro@lamolina.edu.pe>and < reynel@lamolina.edu.pe>.

${ }^{3}$ Center for Conservation and Sustainability, Smithsonian Conservation Biology Institute, Lima - Perú. E-mail: $<$ linaresr@si.edu $>$. *Corresponding author.
}

\begin{abstract}
Studies about the complex processes of forest dynamics in pre-montane and montane forests (between $600-3000 \mathrm{~m}$ altitude) are rare. This study contributes to our knowledge on changes in the floristic composition and population dynamics of woody species in a sub-xerophilous formation immersed in the humid pre-montane and montane forests of Peru. In 2015 we re-measured trees with diameter at breast height equal or greater than $10 \mathrm{~cm}$ in a permanent plot established in 2009 . We recorded 31 species of 25 families, with a Fisher's Alpha diversity index of 7.5. The most abundant and dominant species (including Heteropterys intermedia, Physocalymma scaberrimum, Sapium glandulosum, Tachigali peruviana and Machaerium hirtum) represented $66.25 \%$ of all species in 2009 and $66.36 \%$ in 2015 . The prevalence of these species and others ensures the maintenance of a characteristic seasonally dry forest formation within the census period ( 6.25 years). The dynamics of this forest, with a high rate of recruitment $(3.82 \%)$ and a low rate of mortality $(0.72 \%)$, show favorable conditions for the maintenance of this forest fragment.
\end{abstract}

Keywords: Dry forest; Mortality; Recruitment.

\section{DINÂMICA FLORESTAL DE UMA FORMAÇÃO VEGETAIS SUB-XERÓFILA NO VALOR DE CHANCHAMAYO, DEPARTAMENTO JUNIN, PERU}

\begin{abstract}
RESUMO-Pesquisas sobre os complexos processos de dinâmica da floresta nas florestas montanas e premontanas úmidas (600 a $3000 \mathrm{msnm}$ ) são escassas. Este estudo tem como objetivo contribuir com o conhecimento de mudanças na composição florística e dinâmica populacional de espécies lenhosas em um tipo de formação de planta sub-xerofilica imerso nas florestas úmidas pré-posanas da Selva Central do Peru. Em 2015, todas as árvores com dap $\geq 10 \mathrm{~cm}$ foram novamente medidos em ums Parcela Permanente estabelecida em 2009. 31 espécies foram registradas em 25 famílias e um índice de diversidade Alpha-Fisher de 7.5 foi determinado. As espécies mais abundantes e dominantes em termos relativos mantiveram sua representatividade de $66.25 \%$ em 2009 e 66.36\% em 2015, sendo Heteropterys intermedia, Physocalymma scaberrimum, Sapium glandulosum, Tachigali peruviana e Machaerium hirtum. Uma composição florística é mantida com espécies de formações sazonalmente secas durante o período intercensal (6.25 anos). O dinamismo é influenciado pela alta taxa de recrutamento (3.82\%), em oposição a uma baixa taxa de mortalidade $(0.72 \%)$. Nossos resultados mostram condições favoráveis para a manutenção desse fragmento florestal.
\end{abstract}

Palavras-Chave: Floresta seca; Mortalidade; Recrutamento. 


\section{INTRODUCTION}

The study of forest dynamics in the tropics has mainly focused on lowland rain forests in the Amazon revealing that their structure and dynamics are changing (Nebel et al., 2000; Lewis et al., 2004; Feeley et al., 2011). The species richness in these formations is mainly explained by their forest dynamics rather than by any other factor, showing that disturbance at smaller scales is functionally related with the species richness in a community (Phillips et al., 1994). In terms of tree growth, previous research has suggested that the availability of resources stimulates the net primary production, accelerating the dynamics of basal area and increasing the above-ground biomass (Lewis et al., 2004). However, the specific causes and consequences of such increases are still being discussed.

The study of ecological processes in forests, such as the dynamics of mortality and recruitment rates, and the changes in the floristic composition, can give us insight to and help understand the changing processes of the woody component. Studying the changes in composition improves not only our understanding about the ecology of tropical forests and their response to local and regional disturbances, but also our capacity to predict how future global changes can influence some vital services provided by these ecosystems (Feeley et al., 2011).

Examination of the changing patterns of species composition and their relation to carbon fertilization predictions, of past perturbations, of recovery from extreme drought caused by E1 Niño and of long-term climatic changes, showed that those changes increased the relative proportions of drought-tolerant species. These increases were determined by the occurrence of species along a soil humidity gradient and through a wider rainfall gradient (Feeley et al., 2011). Furthermore, additional research suggested that the compositional transition of tropical forests to more seasonal forest types is a consequence of increasingly dryer conditions which limit the distribution of species (Esquivel-Muelbert et al., 2017).

An optimal scenario to study the contrast between the humid flora and the flora from seasonally dry formations occurs in the central Peruvian rain forest in the Chanchamayo valley. This valley, part of the Perené River basin and located between 600 to 1200 $\mathrm{m}$ above sea level, harbors a sub-xerophilous floristic formation composed of small fragments embedded in

Revista Árvore. 2018;42(6):e420603 a more extensive humid forest matrix. Since much of this valley is exposed to frequent slash and burn and land-use change events, it is important to study and monitor the remaining dry forest fragments over time to understand their dynamics and their contribution to diversity and conservation in these changing premontane landscapes in Central Peru. Especially considering the increase in intensity and length of dry seasons in the Amazon basin (Marengo et al., 2011).

Field observations in the study area suggested that the density of woody individuals was increasing. This could be the result of an increased recruitment rate, but not of mortality. This study sets out to prove this hypothesis. In addition, we also expected changes in the forest structure. These changes were also analyzed from a floristic composition perspective to explore species turnover.

\section{MATERIALS AND METHODS}

\subsection{Study area}

The study area is in the Perené River Valley, San Ramon District, Chanchamayo Province, Junin Region, in Central Peru. Average annual rainfall is between 1500 and $3000 \mathrm{~mm}$, whilst average annual temperature is between 15 and 19 ${ }^{\circ} \mathrm{C}$. Soils are alluvial and support mainly rainforests that have 90 to 147 tree species/ha (Marcelo-Peña and Reynel, 2014). The valley also presents scattered seasonally dry vegetation formations with species that are characteristic of Neotropical dry forests and/or savannas, such as Astronium fraxinifolium (Anacardiaceae), Curatella americana (Dilleniaceae), Machaerium pilosum (Fabaceae), Roupala montana (Proteaceae), Pseudobombax marginatum (Malvaceae), Luehea paniculata (Malvaceae), Dilodendron bipinnatum (Sapindaceae), among others. Previous studies show that these species are absent or rare in the rainforest areas of the valley (Palacios-Ramos, 2017). Many of these areas are burned regularly for crop production.

One of us (SP) stablished a permanent plot for this drier type of vegetation within in a three-hectare area in 2009 (UTM WGS84: 18L 462779 E, 8772597 N). The last recorded fires of anthropic origin in the adjacent areas were in 2005 and 2009.

\subsection{Methodology}

This study compares tree census data from 2009 when the permanent plot $(100 \times 60 \mathrm{~m}$; composed of 15 sub-plots of 20x20m) was stablished (Palacios-Ramos 
and Reynel, 2011) with the second census in 2015, after six years with three months (6.25 years).

Both censuses included the assessment of all trees with DBH (diameter at breast height, $1.30 \mathrm{~m}$ above ground) equal or above $10 \mathrm{~cm}$, following the protocol of Phillips et al. (2009). The second census included: (i) recruits (individuals that reache or passed $10 \mathrm{~cm}$ of DBH in the 2015 census) and (ii) dead individuals. Trees that could not be referred to a previously sampled specimen were collected to be identified later in the herbarium. The samples were processed and deposited in the Universidad Nacional Agraria La Molina Herbarium (MOL: Woody plants collection).

\subsection{Data Analysis}

We constructed a species accumulation curve using each 20x20m sub-plot within the permanent plot (100 permutation for each year we assessed) to show species richness values of the plot according to the size of the sample unit. To assess species diversity, we calculated Fisher's Alpha index, as it allows to compare data from sample units with different abundances. In both cases we used the R programming environment (R Development Core Team, 2017) and the 'vegan' package (Oksanen et al., 2017).

We further calculated woody plant cover values by adding the relative densities (percentage of number of trees) and the relative dominances (percentage of basal area) to analyze the horizontal structure and representativeness of the species.

We analyzed forest dynamics by using mortality and recruitment rates. The mortality rate per annum was calculated according to the exponential growth model in continuous time (Nebel et al., 2000).

$$
\operatorname{Tm}=\frac{\ln \left(N_{0}\right)-\ln \left(N_{0}-N m\right)}{\Delta t}
$$

where: $\mathrm{Tm}=$ annual mortality rate expressed in percentage; $\mathrm{No}=$ number of individuals recorded in the first census; $\mathrm{Nm}=$ number of individuals that died within the $\mathrm{t}$ time interval; $\Delta t=$ time interval $\mathrm{t}$ expressed in years; $\ln =$ natural logarithm.

We calculated the recruitment rate per species by following an exponential function of population increase (Phillips et al., 1994; Nebel et al., 2000).

$$
\mathrm{Tr}=\frac{\ln (N o-N m+N r)-\ln (N o-N m)}{\Delta t}
$$

where: $\operatorname{Tr}=$ recruitment rate or resettlement in percentage; $\mathrm{No}=$ number of individuals recorded during plots setup; $\mathrm{Nr}=$ number of individuals resettled within time interval $\mathrm{t} ; \mathrm{Nm}=$ number of individuals that died during time interval $\mathrm{t} ; \Delta t=$ time interval $\mathrm{t}$ in years. $\ln =$ natural logarithm.

\section{RESULTS}

\subsection{Diversity, floristic composition and structure}

The species accumulation curve for the 2015 recensus shows a stabilization trend (Figure 1). This trend is similar to the estimated values calculated from the 2009 data. Fisher's Alpha diversity was 7.39 in 2009 and 7.5 in 2015 . The number of woody individuals per hectare was 642 , with an increase of $21 \%$ compared to the value estimated in 2009 (532 trees per hectare). In 2009 we recorded 22 families, and added three new families in 2015, each one with one species and only one individual (Annonaceae: Guatteria sp., Vochysiaceae: Vochysia mapirensis and Lacistemataceae: Lacistema aggregatum). Six of the seven species that were represented by only one tree in 2009 kept only one individual in 2015.

The most abundant and dominant species in the 2009 and 2015 censuses were Heteropterys intermedia, Sapium glandulosum, Physocalymma scaberrimum, Tachigali peruviana and Machaerium hirtum. These five species had similar cumulative plant cover values in both inventories (66.3\% y 66.4\%) (Table 1$)$.

Abundance distribution by diametric categories in 2015 showed more individuals in the lower diametric categories, just as in 2009, resulting in

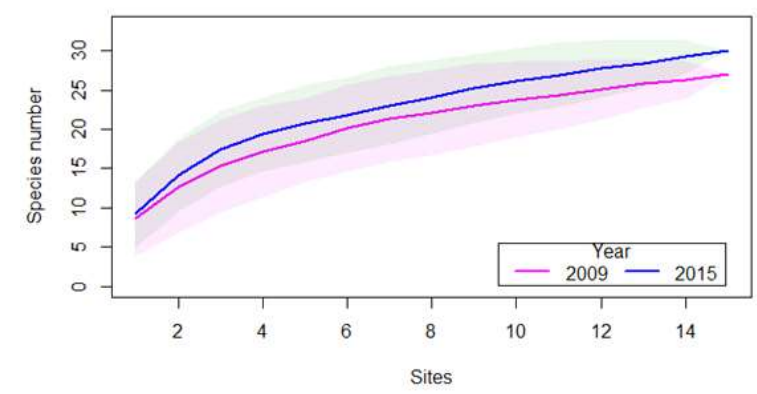

Figure 1 - Species accumulation curve for both censuses, green and pink shaded areas show $95 \%$ confidence envelopes, brown shade shows overlapping region.

Figura 1 - Curvas de acumulação de espécies para os dois censos. 
Table 1 - Relative density (DR, individuals \%), Relative dominance (DoR, basal área \%) and Relative cover value (VC, cover $\%)$ of the 15 most abundant species for 2009 and 2015.

Tabela 1 - Densidade relativa (DR, percentagem de individuos), Dominância relativa (DoR, percentagem de área basal) e Valor de Cobertura (VC, percentagem de cobertura) das 15 espécies mais abundantes para 2009 e 2015.

\begin{tabular}{|c|c|c|c|c|c|c|}
\hline \multirow[t]{2}{*}{ Species } & \multicolumn{3}{|c|}{2009} & \multicolumn{3}{|c|}{2015} \\
\hline & DR & DoR & $\mathrm{VC}$ & DR & DoR & $\mathrm{VC}$ \\
\hline Heteropterys intermedia & 28.84 & 29.55 & 29.20 & 27.53 & 27.47 & 27.50 \\
\hline Sapium glandulosum & 13.79 & 13.43 & 13.61 & 14.29 & 13.62 & 13.96 \\
\hline Physocalymma scaberrimum & 12.85 & 10.23 & 11.54 & 15.06 & 12.00 & 13.53 \\
\hline Tachigali peruviana & 1.57 & 11.73 & 6.65 & 1.82 & 11.49 & 6.66 \\
\hline Machaerium hirtum & 6.27 & 4.25 & 5.26 & 5.71 & 3.73 & 4.72 \\
\hline Cespedesia spathulata & 4.70 & 4.24 & 4.47 & 3.90 & 4.13 & 4.02 \\
\hline Byrsonima spicata & 3.76 & 3.18 & 3.47 & 3.90 & 3.51 & 3.71 \\
\hline Roupala montana & 5.02 & 4.09 & 4.56 & 4.16 & 3.12 & 3.64 \\
\hline Cecropia polystachya & 3.13 & 4.97 & 4.05 & 2.08 & 4.23 & 3.16 \\
\hline Luehea paniculata & 3.45 & 3.20 & 3.33 & 3.12 & 3.07 & 3.10 \\
\hline
\end{tabular}
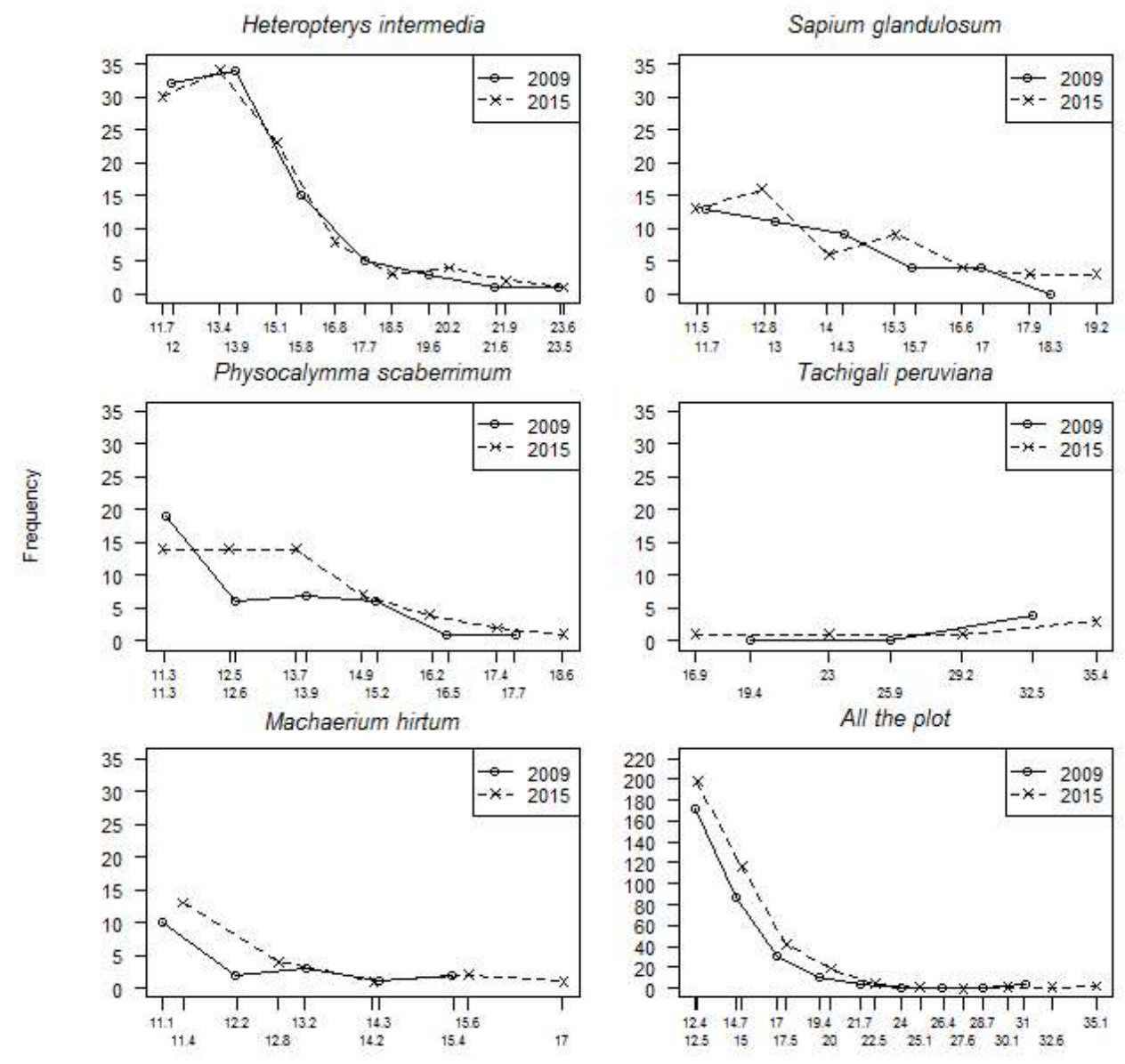

Diametric class

Figure 2 - Abundance distribution by diameter class of selected and pooled species during the 2009 and 2015 censuses. Figura 2 -Distribuição por classes diamétricas de 2009 e 2015.

Revista Árvore. 2018;42(6):e420603 


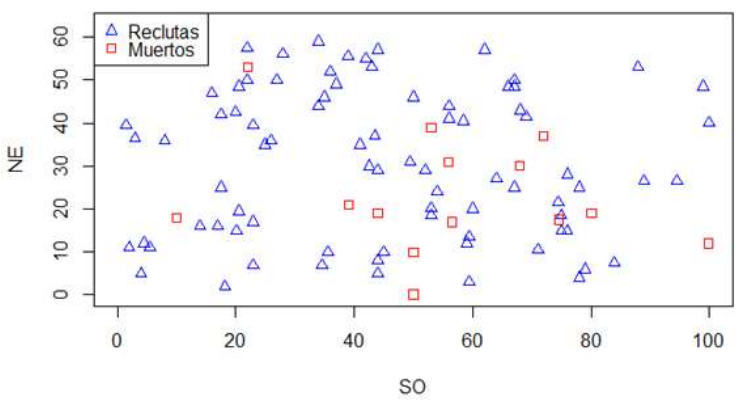

Figure 3 - Spatial distribution of dead and recruited individuals in the permanent plot.

Figura 3 -Distribuição espacial de mortos e recrutas na parcela.

an inverted-j trend. Two of the species with higher cover values kept the same distribution in both censuses (Figure 2).

\subsection{Mortality and recruitment}

Eleven species presented a total of 14 dead individuals in the second census. We also recorded 82 new individuals belonging to 18 species, three of them were species not recorded in the 2009 census. The relatively even distribution of dead individuals and recruits is slightly skewed towards the northwest of the plot (Figure 3). The recruitment of Physocalymma scaberrimum (17), Heteropterys intermedia (15) and Sapium glandulosum (14) represented $56 \%$ of all recruits.

There is a notorious difference between the high recruitment rates $(8.82 \%)$ and the low mortality rates $(0.72 \%) .18$ of the 27 species registered in 2009 showed changes in their dynamics, primarily influenced by the high rate of recruitment (Table 2).

\section{DISCUSSION}

\subsection{Diversity, floristic composition and forest structure}

Four of the five most important species in the plot (Heteropterys intermedia, Physocalymma scaberrimum, Tachigalii peruviana and Machaerium hirtum) are characteristic of seasonally dry forests and/or wooded savannas (Palacios-Ramos and Reynel, 2011; PalaciosRamos, 2017). Luehea paniculata, Roupala montana and Byrsonima spicata are common in seasonally dry formations (Weberbauer, 1945; Garcia-Villacorta, 2009;

Table 2 - Mortality and recruitment rates (2009 and 2015). $\mathrm{N}_{0}$ original stems. $\mathrm{N}_{\mathrm{m}}$ dead stems. $\mathrm{N}_{\mathrm{s}}$ original stems surviving to final census. $\mathrm{N}_{\mathrm{r}}$ recruited stems at final census. $\mathrm{N}_{\mathrm{f}}$ : final stems. Tm: annual mortality rate. Tr: annual recruitment rate.

Tabela 2 - Taxas de mortalidade e recrutamento para 2009 e 2015. $N_{o}$ individuos censo inicial. Nm número de indivíduos mortos. Ns individuos sobreviventes do censo final. Nr recrutas. Nf: indivíduos do censo final. Tm: taxa de mortalidade anual. Tr: taxa de recrutamento anual.

\begin{tabular}{|c|c|c|c|c|c|c|c|}
\hline Species & $\left(\mathrm{N}_{0}\right)$ & $\left(\mathrm{N}_{\mathrm{m}}\right)$ & $\left(\mathrm{N}_{\mathrm{s}}\right)$ & $\left(\mathrm{N}_{\mathrm{r}}\right)$ & $\left(\mathrm{N}_{\mathrm{f}}\right)$ & $(\mathrm{Tm})$ & $(\mathrm{Tr})$ \\
\hline Allophylus floribundus & 7 & & 7 & 8 & 15 & 0.00 & 12.19 \\
\hline Guazuma ulmifolia & 1 & & 1 & 1 & 2 & 0.00 & 11.09 \\
\hline Maprounea guianensis & 2 & & 2 & 2 & 4 & 0.00 & 11.09 \\
\hline Mauria heterophylla & 5 & & 5 & 4 & 9 & 0.00 & 9.40 \\
\hline Schefflera morototoni & 7 & & 7 & 5 & 12 & 0.00 & 8.62 \\
\hline Physocalymma scaberrimum & 41 & & 41 & 17 & 58 & 0.00 & 5.55 \\
\hline Tachigali peruviana & 5 & & 5 & 2 & 7 & 0.00 & 5.38 \\
\hline Byrsonima spicata & 12 & 1 & 11 & 4 & 15 & 1.39 & 4.96 \\
\hline Sapium glandulosum & 44 & 3 & 41 & 14 & 55 & 1.13 & 4.70 \\
\hline Heteropterys intermedia & 92 & 1 & 91 & 15 & 106 & 0.17 & 2.44 \\
\hline Machaerium hirtum & 20 & 1 & 19 & 3 & 22 & 0.82 & 2.35 \\
\hline Luehea paniculata & 11 & & 11 & 1 & 12 & 0.00 & 1.39 \\
\hline Cespedesia spathulata & 15 & 1 & 14 & 1 & 15 & 1.10 & 1.10 \\
\hline Roupala montana & 16 & 1 & 15 & 1 & 16 & 1.03 & 1.03 \\
\hline Trema micrantha & 2 & 1 & 1 & & 1 & 11.09 & 0.00 \\
\hline Cecropia polystachya & 10 & 2 & 8 & & 8 & 3.57 & 0.00 \\
\hline Persea caerulea & 6 & 1 & 5 & & 5 & 2.92 & 0.00 \\
\hline Myrsine pellucida & 10 & 1 & 9 & & 9 & 1.69 & 0.00 \\
\hline Other & 13 & 1 & 12 & 1 & 13 & 0.00 & 0.00 \\
\hline TOTAL & 319 & 14 & 305 & 79 & 384 & 0.72 & 3.69 \\
\hline
\end{tabular}


Linares-Palomino et al., 2011). All these belong to the ten species with the highest plant cover values in the plot, having maintained their representativeness since 2009 (Table 1). In our study area, they have only been registered in the sub-xerophilous formations (PalaciosRamos and Reynel, 2011; Palacios-Ramos, 2017), except for Sapium glandulosum which is considered an ecological generalist species (Linares-Palomino et al., 2011) and also found in the adjacent more humid areas.

Studies have suggested that rainfall seasonality regulate the alpha diversity of Amazonian forests. However, the variation of diversity at local scales is the result of other factors (Ter Steege et al., 2003). For instance, even under high local humidity regimes, local edaphic conditions such as porous soils could increase hydrological stress and decrease diversity (Esquivel-Muelbert et al., 2017). A recent study in our area of interest compared soil diversity and characteristics of the different forest types and showed that the sub-xerophilous forest grew on soils different from those with humid forest growing on it. These different soils allow species to endure conditions with low organic material content, high levels of $\mathrm{pH}$ and interchangeable acidity (Romero, 2017). These conditions could be a limiting factor for the colonization of the adjacent humid forest species.

Another local factor that could influence the dynamics of species is fire. Fire exclusion trials in the Brazilian Cerrado showed that rainforest species are capable of colonizing savannas and compete with the local species assemblage adapted to fire (Geiger et al., 2011), suggesting that a closed canopy forest could develop on the low nutrient soil of the Brazilian Cerrado (Simon and Pennington, 2012). Time is of utmost relevance in this forest - savanna alternation. The transition from saplings to adult trees or from the savanna to forest requires long but unusual intervals without fire. The opposite transitions are favored by prolonged drought and when non-altered forests become flammable (Hoffmann et al., 2012). These statements are relevant for our study area considering that since 2005 and 2009 there have been no more fires. During those events, fires reached the plot border impacting the understory vegetation and the foliage of adjacent trees. However, many of the species in our plot, such as Roupala montana, Byrsonima spicata, Luehea paniculata, Maprounea guianense and Pseudobombax marginatum present adaptations to fire (Palacios-Ramos, 2017). And species such as Curatella americana require fire for reproduction (Penninton and Ratter, 2006). The absence of fire during these six years has not induced major changes in the horizontal structure of the forest (Table 1). The present status could be part of a cyclic succession between more open formations and closed canopy forests, although further censuses would be necessary to confirm it.

Despite the high overall number of recruits and low number of dead individuals, there is an increase of individuals in diametric classes higher than $10 \mathrm{~cm}$ (Figure 1). However, unlike other forests in early successional states (Torres et al., 2012; Muñoz et al., 2014) this increase stabilizes above the $25 \mathrm{~cm}$ diameter class. The smaller diametric classes kept the high number of trees and showed an inverted-j trend. This structure is characteristic of a forest with continuous recruitment and is particularly prevalent in some of the most important species of this forest (Figure 2), providing them whith good possibilities to remain in the plot over a longer term.

\subsection{Mortality and Recruitment}

The annual tree mortality rates reported for Neotropical dry and semi - deciduous forests ranges between $1.9 \%$ and $4.1 \%$ (for DBH $\geq 10 \mathrm{~cm}$ ) (Felfili, 1995; Uslar et al., 2011; Torres et al., 2012) and between 1.3\% and $4.9 \%$ (for $\mathrm{DBH} \geq 5 \mathrm{~cm}$ ) (Aquino et al., 2007; Carbajal and Calvo, 2013; Aguirre, 2016; Calvo-Rodriguez et al., 2017). These values are considerably higher than the mortality rate we report here $(0.72 \%)$. In contrast, the recruitment rate reported for our plot $(3.83 \%)$ is one of the highest for dry forest and semi - deciduous forest, which range between $0.73 \%$ and $7.9 \%$ (for $\mathrm{DBH}$ DAP $\geq 10 \mathrm{~cm}$ ) (Swaine et al., 1990; Felfili, 1995; Uslar et al., 2011; Torres et al, 2012) and between 1.6\% and $8.8 \%$ (for DBH $\geq 5 \mathrm{~cm}$ ) (Aquino et al., 2007; Carbajal and Clavo, 2013; Aguirre, 2016). In a savanna in Ghana Swaine et al. (1990) registered mortality and recruitment rates of $2.3 \%$ and $1.5 \%$, respectively (for $\mathrm{DBH} \geq 10$ $\mathrm{cm}$ ), values also different from those reported in the present study.

Curatella americana and Pseudobombax marginatum are species characteristic of the semideciduous Chiquitano forest and of the Brazilian Cerrados (Furley et al., 1988). They are also present in the subxerophilous formations in Central Peru, usually in areas with an open canopy and with predominance of grasses (Palacios-Ramos and Reynel, 2011). Long-term term

Revista Árvore. 2018;42(6):e420603 
permanence in these sub-xerophilous formations could be compromised since our plot data showed no recruitment. In addition, the increase in the density of trees per hectare of more than $20 \%$ between censuses provides an increasingly closed canopy.

Although the values we report for the mortality and recruitment rates could be strongly influenced by past locally provoked fires, they also show a floristic community with members adapted to those fires. In the dry forest, the floristic composition can be more sensitive to climatic changes associated to rainfall rather than past disturbances during relatively short timescales (Enquist and Enquist, 2011). The intensity of mortality (mortality rate per annum is lower than 5\%) and the distribution of dead individuals per species demonstrate that it is a background mortality. This is part of the processes that occur in the forest community, and could be influenced by auto-shading dependence and radiation capture, the position of trees in the canopy, the successional stage of the forest (Lugo and Scatena, 1996; Melo et al., 2016), the age or size of trees, or the mortality of each species (Lugo and Scatena, 1996). The reported mortality rate has a spatial distribution with no relationship to the limits where past fires occurred (NE vertex of the plot) (Figure 3). This means that the influence of these events does not appear to be evident in the trees we evaluated (with DBH bigger or equal than $10 \mathrm{~cm})$. At the same time, the slight decrease in the spatial distribution of recruitment towards the NW of the plot does not seem to be related to past fire events (NE vertex of the plot) (Figure 3).

The species with the highest recruitment rate constitute only $11 \%$ of the trees in the plot, while their recruitment constitutes less than $25 \%$ of the total recruits registered in 2015. In this context, the influence of these species in this forest could be questioned and we require a longer assessment period to value their relevance. Furthermore, although the most important species showed low recruitment rates, they dominated the forest during the period assessed.

\subsection{Implication for conservation}

Monitoring and assessment to detect patterns of change in the floristic composition of the populations that harbor these sub-xerophylous formations is out reach for the present study. However, the existence of these formations cannot be rejected during conservation planning of the pre- montane forests of the Chanchamayo Valley and the Perené Watershed. Especially when we consider the economic value of many of the species in these forests and their adaptation to dry conditions.

The constraint of most tree taxa in the western Neotropics to the more humid areas shows low generalized tolerance to dry conditions and low capability to acclimatize to them (Esquivel-Muelbert et al., 2017). In the present context of increase in the density and length of dry season in the Amazon Watershed (Marengo et al., 2011) and the increase of temperature (JiménezMuñoz et al., 2013), the results we are showing could be relevant. Particularly considering that the species that occupy a dominant position in the study area regarding dominance and relative density, are species from seasonally dry areas that have morphological adaptations to survive fire (Palacios-Ramos and Reynel, 2011; Palacios-Ramos, 2017), and are already growing in soils with low content of organic material, high levels of $\mathrm{pH}$ and interchangeable acidity (Romero, 2017). These species could be useful for restoration efforts of similar forest systems degraded by anthropic intervention and that are dispersed throughout the valley.

\section{CONCLUSIONS}

The population dynamics of the sub-xerophilous formation is mainly influenced by a high recruitment rate $(3.82 \%)$ and a low mortality rate $(0.72 \%)$. These values are different from other studies in Neotropical seasonally dry formations. These dynamics have not produced noticeable changes in the horizontal structure nor the floristic composition. The maintenance of these conditions suggest they are favorable for the existence of this forest.

The conservation of this sub-xerophilous forest will contribute to their recovery. And if the impact of the pressure over the forest fragments decreases, it can become a source of information for research and monitoring of the seasonally dry forests in Central Peru.

\section{ACKNOWLEDGMENTS}

We thank Robin Fernández, Aniceto Daza and José Luis Marcelo Peña from the Universidad Nacional Agraria La Molina Herbarium (MOL: Woody plants collection), for their contributions to taxonomic identification. To IRD-Selva Central - UNALM for help in establishing and census of the permanent plot. We thank the reviewers 
for their contribution to improve the manuscript. This study was supported by Cienciactiva, CONCYTEC.

\section{REFERENCES}

Aguirre Z. Dinámica de crecimiento de las especies leñosas en una parcela permanente de bosque seco en Loja, Ecuador. Arnaldoa. 2016;23(1):235-46.

Aquino FG, Walter BMT, Ribeiro JF. Woody community dynamics in two fragments of cerrado sensu stricto over a seven-year period (19952002), MA, Brazil. Revista Brasileira de Botânica. 2007;30:111-9.

Calvo-Rodriguez S, Santo MM, Nunes YR, Alvarado JC. Tree diameter growth for three successional stages of Tropical Dry Forest in Minas Gerais, Brazil. Revista Forestal Mesoamericana Kurú. 2017;14(35):24-32.

Carbajal D, Calvo J. Tasas de crecimiento, mortalidad y reclutamiento de vegetación en tres estadios sucesionales del bosque seco tropical, Parque Nacional Santa Rosa, Costa Rica. Revista Forestal Mesoamericana Kurú. 2013;10(25):1-12.

Enquist B, Enquist C. Long-term change within a Neotropical forest: assessing differential functional and floristic responses to disturbance and drought. Global Change Biology. 2011;17:1408-24.

Esquivel-Muelbert A, Baker TR, Dexter KG, Lewis SL, Dexter K, Lewis SL, et al. Seasonal drought limits tree species across the Neotropics. Ecography. 2017;40(5):618-29.

Garcia-Villacorta R. Diversidad, composición y estructura de un hábitat altamente amenazado: los bosques estacionalmente secos de Tarapoto, Perú. Revista Peruana de Biología. 2009;16(1):81-92.

Feeley KJ, Davies SJ, Pèrez R, Hubbell SP, Foster RB. Directional changes in the species composition of a tropical forest. Ecology. 2011;92(4):871-82.

Felfili JM. Growth, recruitment and mortality in the Gama gallery forest in central Brazil over a six-year period (1985-1991). Journal of Tropical Ecology. 1995;11:67-83.

Revista Árvore. 2018;42(6):e420603
Furley P, Ratter J, Gifford D. Observations on the vegetation of estern Matto Grosso, Brazil. III. The woody vegetation and soils of the Morro Fumaca, Torixoreu. Procedings of the Royal Society B. 1988;235:259-80.

Geiger EL, Gostsch SG, Do Vale GD, Haridasan M, Franco AC, Hoffmann WA. Distinct roles of savanna and forest tree species in regeneration following fire suppression in a Brazilian savanna. Journal of Vegetation Science. 2011;22:312-21.

Hoffmann W, Geiger E, Gostsch S, Rossatto D, Silva L, Lau O, et al. Ecological thresholds at the savanna forest boundary: how plant traits, resources and fire govern the distribution of tropical biomes. Ecology Letters. 2012;15(7):759-68.

Jiménez Muñoz JC, Sobrino JA, Mattar C, Malhi Y. Spatial and temporal patterns of the recent warming of the Amazon forest. Journal of Geophysical Research: Atmospheres. 2013;118(11):5204-15.

Lewis S, Phillips O, Baker T, Lloyd J, Malhi Y, Almeida S. et al. Concerted changes in tropical forest structure and dynamics: evidence from 50 South American long-term plots. Philosophical Transactions of the Royal Society B: Biological Sciences. 2004;359:421-36.

Linares-Palomino R, Oliveira-Filho A, Pennington RT. Neotropical seasonally dry forests: diversity, endemism and biogeography of woody plants. In: Dirzo R, Mooney H, Ceballos G, Young H, editors. Seasonally dry tropical forests: biology and conservation. Boca Raton: 2011. p.3-21.

Lugo A, Scatena F. Background and catastrophic tree mortality in tropical moist, wet, and rain forests. Biotropica. 1996;28(4):585-99.

Marcelo-Peña JL, Reynel C. Patrones de diversidad y composición florística de parcelas de evaluación permanente en la selva central de Perú. Rodriguesia. 2014:65(1):35-47.

Marengo JA, Tomasella J, Alves L, Soares W, Rodriguez D. The drought of 2010 in the context of historical droughts in the Amazon region. Geophysical Research Letters. 2011;38(12):L12703.

Melo O, Fernández-Méndez F, Villanueva B. 
Hábitat lumínico, estructura, diversidad y dinámica de los bosques secos tropicales del Alto Magdalena. Colombia Forestal. 2016;20(1):19-30.

Muñoz J, Erazo S, Armijos D. Composición florística y estructura del bosque seco de la quinta experimental "El Chilco" en el suroccidente del Ecuador. CEDAMAZ. 2014;4(1):53-61.

Nebel G, Kvist L, Vanclay J, Vidaurre H. Dinámica de los bosques de la llanura aluvial inundable de la Amazonia Peruana: Efectos de las perturbaciones e implicancias para su manejo y conservación. Folia Amazónica. 2000;11(1-2):65-97.

Oksanen J, Blanchet F, Friendly M, Kindt R, Legendre P, Mcglinn D, et al. Vegan: Community Ecology Package. R package version 2.4-4. 2017. Available: https://CRAN.R-project.org/ package $=$ vegan

Palacios-Ramos S, Reynel C. Una formación vegetal Subxerófila en el Valle de Chanchamayo, Dp. de Junín. Lima: CED-FDA, APRODES; 2011.70p.

Palacios-Ramos S. Dinámica forestal de una formación subxerófila en el Valle de Chanchamayo, Dpto. Junín - Perú [tesis]. Lima: UNALM; 2017.

Pennington RT, Ratter J, editors.Neotropical savanas and seasonally dry forests. Boca Raton: CRC ; 2006.

Phillips O, Baker T, Brienen P. Manual de campo para la remedición y establecimiento de parcelas. In: RAINFOR. 2nd ed. Proyecto PANAMAZONIA. 2009. 24p.

Phillips O, Hall P, Gentry A, Sawyer S, Vásquez R. Dynamics and species richness of tropical rain forests. Proceedings of the National Academy of Sciences. 1994;91(7):2805-9.

R Development Core Team. R: A language and environment for statistical computing. Viena: $\mathrm{R}$ Foundation for Statistical Computing; 2017. Available: http://www.R project.org.

Romero A. Relaciones de la diversidad arbórea y el suelo en la gradiente altitudinal del Valle de Chanchamayo [tesis]. Lima: Universidad Nacional Agraria La Molina; 2017.

Simon M, Pennington T. Evidence for adaptation to fire regimes in the tropical savannas of the Brazilian Cerrado. International Journal of Plant Sciences. 2012;173:711-23.

Swaine M, Lieberman D, Hall J. Structure and dynamics of a tropical dry forest in Ghana. Vegetatio. 1990;88:31-51.

Ter Steege H, Pitman N, Sabatier D, Castellanos H, van der Hout P, Daly DC, et al. A spatial model of tree alpha-diversity and tree den-sity for the Amazon. Biodiversity and Conservation. 2003;12(11):2255-77.

Torres A, Bautista J, Cárdenas M, Vargas A, Londoño V, Rivera K, et al. Dinámica sucesional de un fragmento de bosque seco tropical del Valle del Cauca, Colombia. Biota Colombiana. 2012;13(2):66-85.

UslarY, Mostacedo B, Saldias M. Composición, estructura y dinámica de un bosque seco semidecíduo en Santa Cruz, Bolivia. Ecología en Bolivia. 2011;39(1):25-43.

Weberbauer A. El mundo vegetal de los Andes peruanos. Lima: Lumen; 1945. 